\title{
A Correlation based study using air quality and meteorological parameters for the outbreak of COVID-19 on major affected districts in India
}

Amitesh Gupta ( $\square$ amitesh13gupta14@gmail.com )

RBased Services Pvt. Ltd. https://orcid.org/0000-0002-6664-2351

\section{Research Article}

Keywords: COVID-19, meteorology, air quality, India

Posted Date: July 16th, 2021

DOI: https://doi.org/10.21203/rs.3.rs-711922/v1

License: (c) (1) This work is licensed under a Creative Commons Attribution 4.0 International License.

Read Full License 


\section{Abstract}

Air quality is an important factor for human health conditions. Simultaneously, suitable meteorology poses the circumstances for virus transmission. Hence, we investigated both these two important aspects for the COVID-19 pandemic. We correlated the remote sensing based observations of meteorological parameters and air quality parameters with COVID-19 cases from 657 districts all over the country and found that air quality parameters are playing very crucial role along with a few meteorological parameters for this outbreak. We observed that air temperature, and wind speed were significantly and positively correlated with COVID-19 cases but precipitation and humidity were negatively correlated with confirmed cases. Cloudiness had no significant relation in this aspect. Among the air pollutants, $\mathrm{O}_{3}$ was better correlating with COVID-19 cases. AOD representing the particulate matter concentration also significantly correlated with such cases majorly over Indo-Gangetic plain region. The carbon-pollutants $\mathrm{CO}$ was also very high over the same region. Though $\mathrm{NO}_{2}$ and $\mathrm{SO}_{2}$ were reduced during lockdown, due to the power generation and mining activities both these gases were quite highly correlated over eastern India region. We noted the eastern and western coastal districts of India and districts from the low-lying plain areas had more cases during this pandemic. Our study suggests that improving air quality with proper strict regulations and complete lockdown during the peak of pandemic could reduce the misfortune in all over India. Hence, the summer season could be susceptible and might pose a gesture of seasonality for this disease.

\section{Introduction}

In the 21 st century, the world has been battle-scarred by the pernicious ordeal of coronavirus disease (COVID-19) since early 2020. By the end of May, 2021, a total of 171230341 confirmed cases with a death toll of 3692084 have been registered all over the world. This pneumonia infection caused by SARSCoV-2 had initially broken out in Wuhan, Hubei province, China during late 2019 (Liu et al., 2020a; Zhu et al., 2020a; Zu et al., 2020) and gradually spread all over the world (Bertuzzo et al., 2020; Gorbalenya et al., 2020). Contemplating the hasty unfurl of this virus and its human-to-human transmissibility from contagion (Wang et al., 2020a; Wang et al., 2020b; Wang et al., 2020c), the World Health Organization (WHO) declared this disease to be a global pandemic on March 11, 2020. India, had noted its very first COVID-19 confirmed case on January 27, 2020, and afterwards a total of 27493812 cases have been confirmed by the end of May, 2021 with a death count of 338561 (https://www.covid19india.org/).

Worldwide sundry clinical inspections of COVID-19 have diagnosed respiratory droplets and fomites from contaminated persons as the spawn agent of this lethal disease (Alag, 2020; Ge et al., 2013; Huang et al., 2020a; Jana et al., 2020; Jung et al., 2021; Kunz et al., 2020; Sathian et al., 2020; Tuttle, 2020). Umpteen researchers also reported about analogous symptoms of this disease to MERS and SARS (Holshue et al., 2020; Perlman, 2020; Tan et al., 2005; Wang et al., 2020c). Since the SARS-CoV-2 virus initially causes respiratory damage (Harapan et al., 2020; Khorramdelazad et al., 2021; Larsen et al., 2020; Li et al., 2021), a few researchers have already exhorted about significant association of environmental parameters to

Loading [MathJax]/jax/output/CommonHTML/fonts/TeX/fontdata.js al., 2020; Eslami and Jalili, 2020; Gupta and 
Pradhan, 2020a; Kifer et al., 2021; Rume and Islam, 2020; Saadat et al., 2020; Shakil et al., 2020). Mention Worthy, earlier shedload of studies have conjectured about conspicuous impact of weather conditions on dissemination of respiratory viruses and its seasonality (D'Amato et al., 2018; Pica and Bouvier, 2012; Price et al., 2019). There are also a few global as well as regional studies that had been carried out in the context of China, USA, England, Germany, Spain, Italy, Indonesia, Iran, Pakistan, Bangladesh, India, and found significant correlation between weather parameters and the COVID-19 cases (Ahmadi et al., 2020; Chen et al., 2021; Fadli et al., 2020; Ficetola and Rubolini, 2021; Gupta et al., 2020a; Gupta and Pradhan, 2020b; Islam et al., 2020; Liu et al., 2020b; Ma et al., 2020; Mehmood et al., 2021; Nottmeyer and Sera, 2021; Oliveiros et al., 2020; Qi et al., 2020; Tosepu et al., 2020). On a contrary, a few studies have also reported that meteorological observations are not significantly associated with the outbreak pattern (Iqbal et al., 2020; Jahangiri et al., 2020; Jamil et al., 2020; Mollalo et al., 2020; Shi et al., 2020; Xie and Zhu, 2020). Studies carried out by Bochenek et al., 2021; Borah et al., 2020; Briz-Redón and Serrano-Aroca, 2020; Emediegwu, 2021; Guo et al., 2021; Gupta et al., 2020b; Mecenas et al., 2020; Runkle et al., 2020; Şahin, 2020; Sil and Kumar, 2020 suggested that warm and humid condition seem to foreshorten the proliferation of COVID-19. On the other hand, (Al-Rousan and Al-Najjar, 2020; Awasthi et al., 2020; Bashir et al., 2020a; Fawad et al., 2021; Gupta and Pradhan, 2020a; Kumar and Kumar, 2020; Pani et al., 2020; Sangkham et al., 2021; Selcuk et al., 2021; Sharma et al., 2021) reported that hotter days might be more susceptible for COVID-19 dissemination while the role of humidity was still incongruous (Aidoo et al., 2021; Auler et al., 2020; Gupta et al., 2020c; Kumar, 2020; Yuan et al., 2021). Menebo, 2020 found negative association between precipitation and COVID-19 cases, while Gunthe et al., 2020 found no significance of precipitation and cloudiness for this outbreak.

Studies have enunciated that frequent short-term exposure to air pollutants could aggrandize the likelihood of symptomatic acute respiratory infections among adults (Kim et al., 2018; Kirwa et al., 2021; Xing et al., 2016). Recent studies have stated that both short-term and long-term exposure to different air pollutants could contribute significantly to the higher rates of COVID-19 infections in different parts of the world (Ali and Islam, 2020; Bourdrel et al., 2021; Coker et al., 2020; Gujral and Sinha, 2021; Jain et al., 2021; Li et al., 2020; Lin et al., 2020; Ma et al., 2021; Matthew et al., 2021; Mele et al., 2021; Sharma et al., 2021; Suhaimi et al., 2020; Wu et al., 2020). The carbonaceous pollutants i.e. CO and BC and OC, which also includes the primary and secondary organic carbon, are mainly produced during different anthropogenic activities of biomass burning and fossil fuel combustion, with relatively little contribution from various natural sources (Li et al., 2016; Prabhu et al., 2020; Schmidt, 2011; Wang et al., 2019; Winiger et al., 2016; Zhang and Wang, 2011). AOD, an illustrious indicant of Particulate Matter pollution (Chudnovsky et al., 2014; Engel-Cox et al., 2004; Gupta et al., 2021; Karimian et al., 2016), accounts columnar concentration of gaseous and liquid airborne particles has not been often related to such malady study.

Scanty studies have been carried out on the importance of freshen air for the melioration of human health and to dodge any convalescence (Cragg et al., 2016; Kampa and Castanas, 2008; Manisalidis et al., 2020; White et al., 2019). Since a handful of studies had reckoned that the inferior air quality had Loading [MathJax]/jax/output/CommonHTML/fonts/TeX/fontdata.js bn, hence it becomes also requisite to 
investigate whether the convivial air quality has been benevolent to convalesce the COVID-19 patients in India. Therefore, the present study has been firmed to analyse the association of COVID-19 incidences (i.e. transmission) and recovery cases with weather and air quality parameters across the country, as well as proffered a comparative assessment for estimating confirm and recovery cases availing the non-linear complex relationship.

\section{Data and Methodology}

Counts of Confirmed and Recovered cases for all the available districts in India have been acquired from https://www.covid19india.org/ for the period of April, 2020 to May, 2021. Spatial data for different meteorological parameters - Air Temperature, Bias-corrected Total Precipitation, Humidity, Cloud Cover, Incoming Short-wave Radiation, Wind Speed, and different air quality parameters - Aerosol Optical Depth, Nitrogen di-Oxide, Ozone, Carbon Monoxide, Sulphur di-Oxide, Organic Carbon and Black Carbon have been incorporated in the present study. Remote Sensing based datasets are highly useful for various environmental studies (Bhatt et al., 2021; Das et al., 2017; Das and Gupta, 2021; Gupta et al., 2020b; Gupta et al., 2019; Nanda et al., 2018; Rousta et al., 2020). Monthly mean of these variables were further processed in ArcGIS software, adjoined and related with the monthly cumulative counts of confirmed and recovery cases for each months for each of those selected districts.

Infections and recoveries during 1st COVID-19 waves in India

The district wise spatial distribution of COVID-19 confirmed cases and recoveries during the 1st COVID-19 wave (up to March, 2021) are shown in Fig. 1. It shows that $34.8 \%$ districts had noted cases within the range of 10,000 to $1,00,000$; while only $3 \%$ districts in India registered more than 1 lakh cases during this study period. Noteworthy, most of the districts have registered counts of infective cases within the range of 2500-5000 following the range of 10000-25000. The spatial distribution of cases also depict that the coastal districts were more anguished by misfortune than the districts located in the interior part of the country whereas the districts from the Himalayan Mountains and its foothills had lesser strife during this pandemic. The peak of pandemic was during the early September, 2020 when the daily death counts and confirmed cases were highest, however daily test positivity was highest during July. These trends were at their trough during the winter followed by the post-monsoon seasons but again started to incline since March, 2021.

Pearson's correlation test

Pearson's correlation technique was applied to explore the degree of association of environmental parameters with infected and recovered cases. A correlogram is also being prepared to better represent the interrelation of the variables. 


$$
r=\frac{\sum_{i=1}^{n}\left(E n_{i}-\overline{E n}\right)\left(C_{i}-\bar{C}\right)}{\sqrt{\sum_{i=1}^{n}\left(E n_{i}-\bar{E} n\right)^{2} \sum_{i=1}^{n}\left(C_{i}-\bar{C}\right)^{2}}}
$$

\section{Results And Discussion}

Pearson's correlation test (Fig. 3) found that confirmed cases have significantly $(p<0.05)$ positive correlation with the AT (0.483), ISWR (0.268) and WS (0.391), negative association with Hm (-0.304) and PRC (-0.288); however positive but non-significant $(p>0.05)$ relation with CLD (0.109). It depicts that areas with areas with comparatively higher AT with greater ISWR and drier atmospheric conditions (lower humidity and lesser precipitation) seem to register more infected cases in India. Dowell, 2001; Lowen et al., 2007 had shown that the transmission of respiratory virus via aerosol could be suppressed by higher humid conditions, but enhanced under dry conditions. Thus, the summer conditions become more susceptible for this viral transmission in India. A few studies such as Coccia, 2021; Rendana, 2020; Rosario et al., 2020 have opined that higher wind could lower the emanation of the virus, however we found persuasive correlation between wind and COVID-19 cases in India, thus agreeing to Babu et al., 2020; Gautam et al., 2021. Another crucial reason behind this might be that the districts located near and along the western coast in Kerala, Maharashtra as well as the districts of Tamilnadu, Andhra Pradesh and Odisha located in the eastern coast of India catalogued maximum cases during May to July, 2020 which is the onset duration of monsoon over Indian subcontinent, thus experience higher wind from the sea-side towards the land.

In agreement of numerous scientific research conducted in the last two decades, the link between environmental pollution and chronic illnesses mainly the cardiovascular and respiratory diseases are quite comprehensible (Andersson et al., 2020; Mehta et al., 2013; Orru et al., 2017; Zhang et al., 2019b). In the current study we found all the seven air quality parameters to be significantly and positively correlated with confirmed cases. Figure 2 depicts that monthly confirmed cases was better correlated with monthly average concentration of $\mathrm{O}_{3}(0.588)$ followed by AOD (0.562), $\mathrm{CO}(0.491), \mathrm{NO}_{2}(0.396), \mathrm{BC}$ (0.378) and $\mathrm{SO}_{2}$ (0.302). It confers that concentration of oxidant pollutants had a significant impact on COVID-19 transmission in Indian scenario. There were several hotspots observed in the northern IGP and eastern India contributing detestable amounts of $\mathrm{CO}$ and $\mathrm{NO}_{2}$ that could be held accountable for the appalling air quality in those regions as it might have significantly swayed the exposed individuals to get intensely infected by the coronavirus. Therefore, higher concentration of $\mathrm{O}_{3}$ along with its precursors (CO and $\mathrm{NO}_{2}$ ) could be held noxious for such awful viral emanation especially over northern and eastern part of India. Thus we agreed with Bashir et al., 2020; Li et al., 2020; Pansini and Fornacca, 2020; Zhu et al., 2020 b; Zoran et al., 2020 about the significance of $\mathrm{O}_{3}$, with $\mathrm{CO}$ and $\mathrm{NO}_{2}$ pollution regarding the COVID-19 
fuel combustion and COVID-19 outbreak patterns. Till date, a minimal study has obtained $\mathrm{SO}_{2}$ and $\mathrm{BC}$ to investigate the surging of COVID-19. It was quite distinctive that higher $\mathrm{SO}_{2}$ and coronavirus outbreak were experienced over IGP, Odisha, coastal areas of Gujarat and Maharashtra. Therefore, it can be quite distinctive that the ensued elevated pollution due to outrageous fossil fuel consumption could cause the neighbourhood to be less immune and predisposed to severe respiratory infection like COVID-19 (Kyung and Jeong, 2020; Suhaimi and Jalaludin, 2015; Thurston et al., 2017), hence prominently associated with pulmonary diseases (Anenberg Susan C. et al., 2010; Peters et al., 2001; Rosenthal et al., 2013). Since PM concentration can't be directly assessed through Satellite based observations (Gupta et al., 2021, 2006; Gupta and Christopher, 2009), we correlated satellite AOD with infective cases and found that the IGP was limned with exorbitant AOD where the coronavirus outbreak was also quite austere. Recently, Comunian et al., 2020; Tang et al., 2020 also discussed the evidence of SARS-CoV-2 virus transmission via dust particles. Therefore, considering the elevated AOD over semi-arid north-west India along with scorching summer conditions, and the infective cases from Rajasthan, Punjab, Haryana and Uttar Pradesh during April-June. Interaction between the meteorological parameters and air pollutants' concentrations are quite complex and varying seasonally, and often influenced by the local physiography including the topographic variations such as location of mountains, valleys, or the presence of substantial water bodies such as large rivers, and lakes (Eum et al., 2015; Prabhu et al., 2020). While comparing with the long term average conditions, many studies had acknowledged the imposition of four tier countrywide lockdown for relatively cleaner air in India during April to mid of June, 2020 (Gupta et al., 2020d; Naqvi et al., 2021; Singh and Chauhan, 2020). Even though we found that the IGP followed by the coastal districts of West Bengal, Odisha, Andhra Pradesh, Maharashtra, Kerala, Tamilnadu had inhaled quite bad air where each states had registered more than 30,000 cases during that period. Therefore, it suggests that the shoddy air quality could not be discretely blameworthy for coronavirus dissemination in India, rather bad air with successively increasing AT in summer environment could be held responsible.

\section{Conclusion}

Our conscientious study suggests that the summer tropical environment in India may spare a more affirmative condition for SARS-CoV-2 transmission. Instead of squashing the COVID-19 curve, higher air temperature may significantly assist an augment in pandemic predicament in India. Comparatively higher wind in drier areas could indulge the virus to unfurl more. Besides, the negative correlation between precipitation and infections. The positive correlation between coal blazed pollution and COVID-19 outbreak, as well as the negative association between the recovery count from this disease and prevailing regional pollution levels stoutly suggest that the exorbitant air pollution due to bounteous non-renewable energy generation and its perpetual consumption might perturb the inbred immunity of residents in circumjacent area, and hinder them also in agile recovery from this disease. The concurrent heath tribulation and the interconnection of diseases affecting multiple organs are also decisively discerned during COVID-19 infections. During or in a later stage of treatment, several patients are also condemned to various post-syndrome infections mostly related to cardiovascular and respiratory disorders which 
that the environment needs to be ameliorated immensely by its standards to alleviate such deadly pandemic. The pre-eminence of weather parameters on air quality is indubitable and evinced globally and its significant association with COVID-19 dissemination during a year-long period over India has been certainly revealed through the present study.

\section{Declarations}

Competing interests: The author declares no competing interests.

\section{References}

1. Ahmadi, M., Sharifi, A., Dorosti, S., Jafarzadeh Ghoushchi, S., Ghanbari, N., 2020. Investigation of effective climatology parameters on COVID-19 outbreak in Iran. Science of The Total Environment 729, 138705. https://doi.org/10.1016/j.scitotenv.2020.138705

2. Aidoo, E.N., Adebanji, A.O., Awashie, G.E., Appiah, S.K., 2021. The effects of weather on the spread of COVID-19: evidence from Ghana. Bull Natl Res Cent 45, 20. https://doi.org/10.1186/s42269-02100484-3

3. Alag, S., 2020. Analysis of COVID-19 clinical trials: A data-driven, ontology-based, and natural language processing approach. PLOS ONE 15, e0239694.

https://doi.org/10.1371/journal.pone.0239694

4. Ali, N., Islam, F., 2020. The Effects of Air Pollution on COVID-19 Infection and Mortality-A Review on Recent Evidence. Front Public Health 8. https://doi.org/10.3389/fpubh.2020.580057

5. Al-Rousan, N., Al-Najjar, H., 2020. The correlation between the spread of COVID-19 infections and weather variables in 30 Chinese provinces and the impact of Chinese government mitigation plans. Eur Rev Med Pharmacol Sci 24, 4565-4571. https://doi.org/10.26355/eurrev_202004_21042

6. Andersson, E.M., Ögren, M., Molnár, P., Segersson, D., Rosengren, A., Stockfelt, L., 2020. Road traffic noise, air pollution and cardiovascular events in a Swedish cohort. Environmental Research 185, 109446. https://doi.org/10.1016/j.envres.2020.109446

7. Anenberg Susan C., Horowitz Larry W., Tong Daniel Q., West J. Jason, 2010. An Estimate of the Global Burden of Anthropogenic Ozone and Fine Particulate Matter on Premature Human Mortality Using Atmospheric Modeling. Environmental Health Perspectives 118, 1189-1195. https://doi.org/10.1289/ehp.0901220

8. Auler, A.C., Cássaro, F.A.M., da Silva, V.O., Pires, L.F., 2020. Evidence that high temperatures and intermediate relative humidity might favor the spread of COVID-19 in tropical climate: A case study for the most affected Brazilian cities. Science of The Total Environment 729, 139090. https://doi.org/10.1016/j.scitotenv.2020.139090

9. Awasthi, A., Sharma, A., Kaur, P., Gugamsetty, B., Kumar, A., 2020. Statistical interpretation of environmental influencing parameters on COVID-19 during the lockdown in Delhi, India. Environ Dev 
10. Azuma, K., Yanagi, U., Kagi, N., Kim, H., Ogata, M., Hayashi, M., 2020. Environmental factors involved in SARS-CoV-2 transmission: effect and role of indoor environmental quality in the strategy for COVID-19 infection control. Environmental Health and Preventive Medicine 25, 66. https://doi.org/10.1186/s12199-020-00904-2

11. Babu, S.R., Rao, N.N., Kumar, S.V., Paul, S., Pani, S.K., 2020. Plausible Role of Environmental Factors on COVID-19 Transmission in the Megacity Delhi, India. Aerosol Air Qual. Res. 20, 2075-2084. https://doi.org/10.4209/aaqr.2020.06.0314

12. Bashir, M.F., Ma, B., Bilal, Komal, B., Bashir, M.A., Tan, D., Bashir, M., 2020a. Correlation between climate indicators and COVID-19 pandemic in New York, USA. Science of The Total Environment 728, 138835. https://doi.org/10.1016/j.scitotenv.2020.138835

13. Bashir, M.F., Ma, B.J., Bilal, null, Komal, B., Bashir, M.A., Farooq, T.H., lqbal, N., Bashir, M., $2020 b$. Correlation between environmental pollution indicators and COVID-19 pandemic: A brief study in Californian context. Environ Res 187, 109652. https://doi.org/10.1016/j.envres.2020.109652

14. Benjamin, S.F., 1975. Study of Topographical Effects on Dispersion of Pollution, in: Frenkiel, F.N., Munn, R.E. (Eds.), Advances in Geophysics, International Union of Theoretical and Applied Mechanics and International Union of Geodesy and Geophysics. Elsevier, p. 380. https://doi.org/10.1016/S0065-2687(08)60602-0

15. Bertuzzo, E., Mari, L., Pasetto, D., Miccoli, S., Casagrandi, R., Gatto, M., Rinaldo, A., 2020. The geography of COVID-19 spread in Italy and implications for the relaxation of confinement measures. Nat Commun 11, 4264. https://doi.org/10.1038/s41467-020-18050-2

16. Bhatt, C.M., Gupta, A., Roy, A., Dalal, P., Chauhan, P., 2021. Geospatial analysis of September, 2019 floods in the lower gangetic plains of Bihar using multi-temporal satellites and river gauge data. Geomatics, Natural Hazards and Risk 12, 84-102. https://doi.org/10.1080/19475705.2020.1861113

17. Bherwani, H., Gupta, A., Anjum, S., Anshul, A., Kumar, R., 2020. Exploring dependence of COVID-19 on environmental factors and spread prediction in India. npj Climate and Atmospheric Science 3, 1-13. https://doi.org/10.1038/s41612-020-00142-x

18. Bochenek, B., Jankowski, M., Gruszczynska, M., Nykiel, G., Gruszczynski, M., Jaczewski, A., Ziemianski, M., Pyrc, R., Figurski, M., Pinkas, J., 2021. Impact of Meteorological Conditions on the Dynamics of the COVID-19 Pandemic in Poland. Int J Environ Res Public Health 18. https://doi.org/10.3390/ijerph18083951

19. Borah, M.J., Hazarika, B., Panda, S.K., Nieto, J.J., 2020. Examining the correlation between the weather conditions and COVID-19 pandemic in India: A mathematical evidence. Results in Physics 19, 103587. https://doi.org/10.1016/j.rinp.2020.103587

20. Bourdrel, T., Annesi-Maesano, I., Alahmad, B., Maesano, C.N., Bind, M.-A., 2021. The impact of outdoor air pollution on COVID-19: a review of evidence from in vitro, animal, and human studies. European Respiratory Review 30. https://doi.org/10.1183/16000617.0242-2020

21. Briz-Redón, Á., Serrano-Aroca, Á., 2020. A spatio-temporal analysis for exploring the effect of 
https://doi.org/10.1016/j.scitotenv.2020.138811

22. Chauhan, A.J., Johnston, S.L., 2003. Air pollution and infection in respiratory illness. British Medical Bulletin 68, 95-112. https://doi.org/10.1093/bmb/ldg022

23. Chen, S., Prettner, K., Kuhn, M., Geldsetzer, P., Wang, C., Bärnighausen, T., Bloom, D.E., 2021. Climate and the spread of COVID-19. Sci Rep 11, 9042. https://doi.org/10.1038/s41598-021-87692-z

24. Chudnovsky, A.A., Koutrakis, P., Kloog, I., Melly, S., Nordio, F., Lyapustin, A., Wang, Y., Schwartz, J., 2014. Fine particulate matter predictions using high resolution Aerosol Optical Depth (AOD) retrievals. Atmospheric Environment 89, 189-198. https://doi.org/10.1016/j.atmosenv.2014.02.019

25. Ciencewicki, J., Jaspers, I., 2007. Air Pollution and Respiratory Viral Infection. Inhalation Toxicology 19, 1135-1146. https://doi.org/10.1080/08958370701665434

26. Coccia, M., 2021. How do low wind speeds and high levels of air pollution support the spread of COVID-19? Atmospheric Pollution Research 12, 437-445. https://doi.org/10.1016/j.apr.2020.10.002

27. Coker, E.S., Cavalli, L., Fabrizi, E., Guastella, G., Lippo, E., Parisi, M.L., Pontarollo, N., Rizzati, M., Varacca, A., Vergalli, S., 2020. The Effects of Air Pollution on COVID-19 Related Mortality in Northern Italy. Environ Resource Econ 76, 611-634. https://doi.org/10.1007/s10640-020-00486-1

28. Comunian, S., Dongo, D., Milani, C., Palestini, P., 2020. Air Pollution and COVID-19: The Role of Particulate Matter in the Spread and Increase of COVID-19's Morbidity and Mortality. Int J Environ Res Public Health 17. https://doi.org/10.3390/ijerph17124487

29. Cragg, L., Williams, S., Chavannes, N.H., 2016. FRESH AIR: an implementation research project funded through Horizon 2020 exploring the prevention, diagnosis and treatment of chronic respiratory diseases in low-resource settings. npj Primary Care Respiratory Medicine 26, 1-5. https://doi.org/10.1038/npjpcrm.2016.35

30. D’Amato, M., Molino, A., Calabrese, G., Cecchi, L., Annesi-Maesano, I., D’Amato, G., 2018. The impact of cold on the respiratory tract and its consequences to respiratory health. Clinical and Translational Allergy 8, 20. https://doi.org/10.1186/s13601-018-0208-9

31. Das, S., Gupta, A., 2021. Multi-criteria decision based geospatial mapping of flood susceptibility and temporal hydro-geomorphic changes in the Subarnarekha basin, India. Geoscience Frontiers 12, 101206. https://doi.org/10.1016/j.gsf.2021.101206

32. Das, S., Gupta, A., Ghosh, S., 2017. Exploring groundwater potential zones using MIF technique in semi-arid region: a case study of Hingoli district, Maharashtra. Spat. Inf. Res. 25, 749-756. https://doi.org/10.1007/s41324-017-0144-0

33. Dowell, S.F., 2001. Seasonal variation in host susceptibility and cycles of certain infectious diseases. Emerg Infect Dis 7, 369-374. https://doi.org/10.3201/eid0703.010301

34. Emediegwu, L.E., 2021. Health impacts of daily weather fluctuations: Empirical evidence from COVID19 in U.S. counties. Journal of Environmental Management 291, 112662.

https://doi.org/10.1016/j.jenvman.2021.112662

35. Engel-Cox, J.A., Hoff, R.M., Haymet, A.D.J., 2004. Recommendations on the Use of Satellite RemoteLoading [MathJax]/jax/output/CommonHTML/fonts/TeX/fontdata.js \& Waste Management Association 54, 1360- 
1371. https://doi.org/10.1080/10473289.2004.10471005

36. Eslami, H., Jalili, M., 2020. The role of environmental factors to transmission of SARS-CoV-2 (COVID19). AMB Express 10. https://doi.org/10.1186/s13568-020-01028-0

37. Eum, Y., Song, I., Kim, H.-C., Leem, J.-H., Kim, S.-Y., 2015. Computation of geographic variables for air pollution prediction models in South Korea. Environ Health Toxicol 30.

https://doi.org/10.5620/eht.e2015010

38. Fadli, A., Nugraha, A.W.W., Aliim, M.S., Taryana, A., Kurniawan, Y.I., Purnomo, W.H., 2020. Simple Correlation Between Weather and COVID-19 Pandemic Using Data Mining Algorithms. IOP Conf. Ser.: Mater. Sci. Eng. 982, 012015. https://doi.org/10.1088/1757-899X/982/1/012015

39. Fawad, M., Mubarik, S., Malik, S.S., Ren, J., 2021. Statistical analysis of COVID-19 infection caused by environmental factors: Evidence from Pakistan. Life Sci 269, 119093. https://doi.org/10.1016/j.Ifs.2021.119093

40. Ficetola, G.F., Rubolini, D., 2021. Containment measures limit environmental effects on COVID-19 early outbreak dynamics. Science of The Total Environment 761, 144432. https://doi.org/10.1016/j.scitotenv.2020.144432

41. Gautam, S., Samuel, C., Gautam, A.S., Kumar, S., 2021. Strong link between coronavirus count and bad air: a case study of India. Environ Dev Sustain. https://doi.org/10.1007/s10668-021-01366-4

42. Ge, X.-Y., Li, J.-L., Yang, X.-L., Chmura, A.A., Zhu, G., Epstein, J.H., Mazet, J.K., Hu, B., Zhang, W., Peng, C., Zhang, Y.-J., Luo, C.-M., Tan, B., Wang, N., Zhu, Y., Crameri, G., Zhang, S.-Y., Wang, L.-F., Daszak, P., Shi, Z.-L., 2013. Isolation and characterization of a bat SARS-like coronavirus that uses the ACE2 receptor. Nature 503, 535-538. https://doi.org/10.1038/nature12711

43. Gorbalenya, A.E., Baker, S.C., Baric, R.S., Groot, R.J. de, Drosten, C., Gulyaeva, A.A., Haagmans, B.L., Lauber, C., Leontovich, A.M., Neuman, B.W., Penzar, D., Perlman, S., Poon, L.L.M., Samborskiy, D., Sidorov, I.A., Sola, I., Ziebuhr, J., 2020. Severe acute respiratory syndrome-related coronavirus: The species and its viruses - a statement of the Coronavirus Study Group. bioRxiv 2020.02.07.937862. https://doi.org/10.1101/2020.02.07.937862

44. Guan, W., Ni, Z., Hu, Yu, Liang, W., Ou, C., He, J., Liu, L., Shan, H., Lei, C., Hui, D.S.C., Du, B., Li, L., Zeng, G., Yuen, K.-Y., Chen, R., Tang, C., Wang, T., Chen, P., Xiang, J., Li, S., Wang, Jin-lin, Liang, Z., Peng, Y., Wei, L., Liu, Y., Hu, Ya-hua, Peng, P., Wang, Jian-ming, Liu, J., Chen, Z., Li, G., Zheng, Z., Qiu, S., Luo, J., Ye, C., Zhu, S., Zhong, N., 2020. Clinical Characteristics of Coronavirus Disease 2019 in China. N Engl J Med 382, 1708-1720. https://doi.org/10.1056/NEJMoa2002032

45. Gujral, H., Sinha, A., 2021. Association between exposure to airborne pollutants and COVID-19 in Los Angeles, United States with ensemble-based dynamic emission model. Environmental Research 194, 110704. https://doi.org/10.1016/j.envres.2020.110704

46. Gunthe, S.S., Swain, B., Patra, S.S., Amte, A., 2020. On the global trends and spread of the COVID-19 outbreak: preliminary assessment of the potential relation between location-specific temperature and UV index. J Public Health (Berl.). https://doi.org/10.1007/s10389-020-01279-y 
47. Guo, C., Bo, Y., Lin, C., Li, H.B., Zeng, Y., Zhang, Y., Hossain, M.S., Chan, J.W.M., Yeung, D.W., Kwok, K.O., Wong, S.Y.S., Lau, A.K.H., Lao, X.Q., 2021. Meteorological factors and COVID-19 incidence in 190 countries: An observational study. Sci Total Environ 757, 143783.

https://doi.org/10.1016/j.scitotenv.2020.143783

48. Gupta, A., Asopa, U., Bhattacharjee, R., 2019. Land Subsidence Monitoring in Jagadhri City Using Sentinel 1 Data and DInSAR Processing. Proceedings 24, 25. https://doi.org/10.3390/IECG201906230

49. Gupta, A., Banerjee, S., Das, S., 2020a. Significance of geographical factors to the COVID-19 outbreak in India. Model. Earth Syst. Environ. 6, 2645-2653. https://doi.org/10.1007/s40808-020-00838-2

50. Gupta, A., Bhatt, C.M., Roy, A., Chauhan, P., 2020b. COVID-19 lockdown a window of opportunity to understand the role of human activity on forest fire incidences in the Western Himalaya, India. CURRENT SCIENCE 119, 9.

51. Gupta, A., Kant, Y., Mitra, D., Chauhan, P., 2021. Spatio-temporal distribution of INSAT-3D AOD derived particulate matter concentration over India. Atmospheric Pollution Research 12, 159-172. https://doi.org/10.1016/j.apr.2020.08.031

52. Gupta, A., Pradhan, B., 2020a. Impact of Daily Weather on COVID-19 outbreak in India. https://doi.org/10.1101/2020.06.15.20131490

53. Gupta, A., Pradhan, B., 2020b. Assessment of temporal trend of COVID-19 outbreak in India. https://doi.org/10.31219/osf.io/qyre6

54. Gupta, A., Pradhan, B., Maulud, K.N.A., 2020c. Estimating the Impact of Daily Weather on the Temporal Pattern of COVID-19 Outbreak in India. Earth Syst Environ 4, 523-534. https://doi.org/10.1007/s41748-020-00179-1

55. Gupta, P., Christopher, S.A., 2009. Particulate matter air quality assessment using integrated surface, satellite, and meteorological products: 2. A neural network approach. J. Geophys. Res. 114, D20205. https://doi.org/10.1029/2008JD011497

56. Gupta, P., Christopher, S.A., Wang, J., Gehrig, R., Lee, Y., Kumar, N., 2006. Satellite remote sensing of particulate matter and air quality assessment over global cities. Atmospheric Environment 40, 58805892. https://doi.org/10.1016/j.atmosenv.2006.03.016

57. Gupta, S., Raghuwanshi, G.S., Chanda, A., 2020. Effect of weather on COVID-19 spread in the US: A prediction model for India in 2020. Science of The Total Environment 728, 138860.

https://doi.org/10.1016/j.scitotenv.2020.138860

58. Harapan, H., Itoh, N., Yufika, A., Winardi, W., Keam, S., Te, H., Megawati, D., Hayati, Z., Wagner, A.L., Mudatsir, M., 2020. Coronavirus disease 2019 (COVID-19): A literature review. Journal of Infection and Public Health 13, 667-673. https://doi.org/10.1016/j.jiph.2020.03.019

59. Hewson, E.W., Olsson, L.E., 1967. Lake Effects on Air Pollution Dispersion. Journal of the Air Pollution Control Association 17, 757-761. https://doi.org/10.1080/00022470.1967.10469069

60. Holshue, M.L., DeBolt, C., Lindquist, S., Lofy, K.H., Wiesman, J., Bruce, H., Spitters, C., Ericson, K., Loading [MathJax]/jax/output/CommonHTML/fonts/TeX/fontdata.js Il, A., Gerber, S.I., Kim, L., Tong, S., Lu, X., 
Lindstrom, S., Pallansch, M.A., Weldon, W.C., Biggs, H.M., Uyeki, T.M., Pillai, S.K., 2020. First Case of 2019 Novel Coronavirus in the United States. New England Journal of Medicine 382, 929-936. https://doi.org/10.1056/NEJMoa2001191

61. Huang, C., Wang, Y., Li, X., Ren, L., Zhao, J., Hu, Y., Zhang, L., Fan, G., Xu, J., Gu, X., Cheng, Z., Yu, T., Xia, J., Wei, Y., Wu, W., Xie, X., Yin, W., Li, H., Liu, M., Xiao, Y., Gao, H., Guo, L., Xie, J., Wang, G., Jiang, R., Gao, Z., Jin, Q., Wang, J., Cao, B., 2020. Clinical features of patients infected with 2019 novel coronavirus in Wuhan, China. The Lancet 395, 497-506. https://doi.org/10.1016/S01406736(20)30183-5

62. Iqbal, N., Fareed, Z., Shahzad, F., He, X., Shahzad, U., Lina, M., 2020. The nexus between COVID-19, temperature and exchange rate in Wuhan city: New findings from partial and multiple wavelet coherence. Science of The Total Environment 729, 138916.

https://doi.org/10.1016/j.scitotenv.2020.138916

63. Islam, A.R.Md.T., Hasanuzzaman, Md., Azad, Md.A.K., Salam, R., Toshi, F.Z., Khan, Md.S.I., Alam, G.M.M., Ibrahim, S.M., 2020. Effect of meteorological factors on COVID-19 cases in Bangladesh. Environ Dev Sustain. https://doi.org/10.1007/s10668-020-01016-1

64. Jahangiri, Mehdi, Jahangiri, Milad, Najafgholipour, M., 2020. The sensitivity and specificity analyses of ambient temperature and population size on the transmission rate of the novel coronavirus (COVID-19) in different provinces of Iran. Sci Total Environ 728, 138872.

https://doi.org/10.1016/j.scitotenv.2020.138872

65. Jain, M., Sharma, G.D., Goyal, M., Kaushal, R., Sethi, M., 2021. Econometric analysis of COVID-19 cases, deaths, and meteorological factors in South Asia. Environ Sci Pollut Res 28, 28518-28534. https://doi.org/10.1007/s11356-021-12613-6

66. Jamil, T., Alam, I.S., Gojobori, T., Duarte, C., 2020. No Evidence for Temperature-Dependence of the COVID-19 Epidemic. medRxiv 2020.03.29.20046706. https://doi.org/10.1101/2020.03.29.20046706

67. Jana, S., Gupta, A., Nath, A., 2020. Assessment of Global Performance on COVID-19 Research during 1990-2019: An Exploratory Scientometric Analysis 19.

68. Jung, R.G., Di Santo, P., Clifford, C., Prosperi-Porta, G., Skanes, S., Hung, A., Parlow, S., Visintini, S., Ramirez, F.D., Simard, T., Hibbert, B., 2021. Methodological quality of COVID-19 clinical research. Nature Communications 12, 943. https://doi.org/10.1038/s41467-021-21220-5

69. Kampa, M., Castanas, E., 2008. Human health effects of air pollution. Environmental Pollution, Proceedings of the 4th International Workshop on Biomonitoring of Atmospheric Pollution (With Emphasis on Trace Elements) 151, 362-367. https://doi.org/10.1016/j.envpol.2007.06.012

70. Karimian, H., Li, Q., Li, C., Jin, L., Fan, J., Li, Y., 2016. An Improved Method for Monitoring Fine Particulate Matter Mass Concentrations via Satellite Remote Sensing. Aerosol Air Qual. Res. 16, 1081-1092. https://doi.org/10.4209/aaqr.2015.06.0424

71. Khorramdelazad, H., Kazemi, M.H., Najafi, A., Keykhaee, M., Zolfaghari Emameh, R., Falak, R., 2021. Immunopathological similarities between COVID-19 and influenza: Investigating the consequences 
72. Kifer, D., Bugada, D., Villar-Garcia, J., Gudelj, I., Menni, C., Sudre, C., Vučković, F., Ugrina, I., Lorini, L.F., Posso, M., Bettinelli, S., Ughi, N., Maloberti, A., Epis, O., Giannattasio, C., Rossetti, C., Kalogjera, L., Peršec, J., Ollivere, L., Ollivere, B.J., Yan, H., Cai, T., Aithal, G.P., Steves, C.J., Kantele, A., Kajova, M., Vapalahti, O., Sajantila, A., Wojtowicz, R., Wierzba, W., Krol, Z., Zaczynski, A., Zycinska, K., Postula, M., Lukšić, I., Čivljak, R., Markotić, A., Brachmann, J., Markl, A., Mahnkopf, C., Murray, B., Ourselin, S., Valdes, A.M., Horcajada, J.P., Castells, X., Pascual, J., Allegri, M., Primorac, D., Spector, T.D., Barrios, C., Lauc, G., 2021. Effects of Environmental Factors on Severity and Mortality of COVID-19. Front. Med. 7. https://doi.org/10.3389/fmed.2020.607786

73. Kim, D., Chen, Z., Zhou, L.-F., Huang, S.-X., 2018. Air pollutants and early origins of respiratory diseases. Chronic Dis Transl Med 4, 75-94. https://doi.org/10.1016/j.cdtm.2018.03.003

74. Kirwa, K., Eckert, C.M., Vedal, S., Hajat, A., Kaufman, J.D., 2021. Ambient air pollution and risk of respiratory infection among adults: evidence from the multiethnic study of atherosclerosis (MESA). BMJ Open Respiratory Research 8, e000866. https://doi.org/10.1136/bmjresp-2020-000866

75. Kumar, G., Kumar, R.R., 2020. A correlation study between meteorological parameters and COVID-19 pandemic in Mumbai, India. Diabetes \& Metabolic Syndrome: Clinical Research \& Reviews 14, 17351742. https://doi.org/10.1016/j.dsx.2020.09.002

76. Kumar, S., 2020. Effect of meteorological parameters on spread of COVID-19 in India and air quality during lockdown. Sci Total Environ 745, 141021. https://doi.org/10.1016/j.scitotenv.2020.141021

77. Kunz, C.U., Jörgens, S., Bretz, F., Stallard, N., Lancker, K.V., Xi, D., Zohar, S., Gerlinger, C., Friede, T., 2020. Clinical Trials Impacted by the COVID-19 Pandemic: Adaptive Designs to the Rescue?

Statistics in Biopharmaceutical Research 12, 461-477.

https://doi.org/10.1080/19466315.2020.1799857

78. Kyung, S.Y., Jeong, S.H., 2020. Particulate-Matter Related Respiratory Diseases. Tuberc Respir Dis (Seoul) 83, 116-121. https://doi.org/10.4046/trd.2019.0025

79. Larsen, J.R., Martin, M.R., Martin, J.D., Kuhn, P., Hicks, J.B., 2020. Modeling the Onset of Symptoms of COVID-19. Front. Public Health 8. https://doi.org/10.3389/fpubh.2020.00473

80. Li, C., Bosch, C., Kang, S., Andersson, A., Chen, P., Zhang, Q., Cong, Z., Chen, B., Qin, D., Gustafsson, Ö., 2016. Sources of black carbon to the Himalayan-Tibetan Plateau glaciers. Nature Communications 7, 12574. https://doi.org/10.1038/ncomms12574

81. Li, H., Xu, X.-L., Dai, D.-W., Huang, Z.-Y., Ma, Z., Guan, Y.-J., 2020. Air pollution and temperature are associated with increased COVID-19 incidence: A time series study. International Journal of Infectious Diseases 97, 278-282. https://doi.org/10.1016/j.ijid.2020.05.076

82. Li, P., Wang, Y., Peppelenbosch, M.P., Ma, Z., Pan, Q., 2021. Systematically comparing COVID-19 with the 2009 influenza pandemic for hospitalized patients. Int J Infect Dis 102, 375-380. https://doi.org/10.1016/j.ijid.2020.11.127

83. Li, R., Gong, J., Chen, L., Wang, Z., 2015. Estimating Ground-Level PM2.5 Using Fine-Resolution Satellite Data in the Megacity of Beijing, China. Aerosol Air Qual. Res. 15, 1347-1356. 
84. Lin, S., Wei, D., Sun, Y., Chen, K., Yang, L., Liu, B., Huang, Q., Paoliello, M.M.B., Li, H., Wu, S., 2020. Region-specific air pollutants and meteorological parameters influence COVID-19: A study from mainland China. Ecotoxicology and Environmental Safety 204, 111035. https://doi.org/10.1016/j.ecoenv.2020.111035

85. Liu, J., Zhou, J., Yao, J., Zhang, X., Li, L., Xu, X., He, X., Wang, B., Fu, S., Niu, T., Yan, J., Shi, Y., Ren, X., Niu, J., Zhu, W., Li, S., Luo, B., Zhang, K., 2020. Impact of meteorological factors on the COVID-19 transmission: A multi-city study in China. Science of The Total Environment 726, 138513. https://doi.org/10.1016/j.scitotenv.2020.138513

86. Liu, T., Hu, J., Xiao, J., He, G., Kang, M., Rong, Z., Lin, L., Zhong, H., Huang, Q., Deng, A., Zeng, W., Tan, X., Zeng, S., Zhu, Z., Li, J., Gong, D., Wan, D., Chen, S., Guo, L., Li, Y., Sun, L., Liang, W., Song, T., He, J., Ma, W., 2020. Time-varying transmission dynamics of Novel Coronavirus Pneumonia in China. bioRxiv 2020.01.25.919787. https://doi.org/10.1101/2020.01.25.919787

87. Lowen, A.C., Mubareka, S., Steel, J., Palese, P., 2007. Influenza Virus Transmission Is Dependent on Relative Humidity and Temperature. PLOS Pathogens 3, e151. https://doi.org/10.1371/journal.ppat.0030151

88. Ma, Y., Cheng, B., Shen, J., Wang, H., Feng, F., Zhang, Y., Jiao, H., 2021. Association between environmental factors and COVID-19 in Shanghai, China. Environ Sci Pollut Res Int 1-9. https://doi.org/10.1007/s11356-021-13834-5

89. Ma, Y., Zhao, Y., Liu, J., He, X., Wang, B., Fu, S., Yan, J., Niu, J., Zhou, J., Luo, B., 2020. Effects of temperature variation and humidity on the death of COVID-19 in Wuhan, China. Science of The Total Environment 724, 138226. https://doi.org/10.1016/j.scitotenv.2020.138226

90. Mahapatra, P.S., Puppala, S.P., Adhikary, B., Shrestha, K.L., Dawadi, D.P., Paudel, S.P., Panday, A.K., 2019. Air quality trends of the Kathmandu Valley: A satellite, observation and modeling perspective. Atmospheric Environment 201, 334-347. https://doi.org/10.1016/j.atmosenv.2018.12.043

91. Manisalidis, I., Stavropoulou, E., Stavropoulos, A., Bezirtzoglou, E., 2020. Environmental and Health Impacts of Air Pollution: A Review. Front Public Health 8. https://doi.org/10.3389/fpubh.2020.00014

92. Matthew, O.J., Eludoyin, A.O., Oluwadiya, K.S., 2021. Spatio-temporal variations in COVID-19 in relation to the global climate distribution and fluctuations. Spatial and Spatio-temporal Epidemiology 37, 100417. https://doi.org/10.1016/j.sste.2021.100417

93. Mecenas, P., Bastos, R.T. da R.M., Vallinoto, A.C.R., Normando, D., 2020. Effects of temperature and humidity on the spread of COVID-19: A systematic review. PLOS ONE 15, e0238339. https://doi.org/10.1371/journal.pone.0238339

94. Mehmood, K., Bao, Y., Abrar, M.M., Petropoulos, G.P., Saifullah, Soban, A., Saud, S., Khan, Z.A., Khan, S.M., Fahad, S., 2021. Spatiotemporal variability of COVID-19 pandemic in relation to air pollution, climate and socioeconomic factors in Pakistan. Chemosphere 271, 129584. https://doi.org/10.1016/j.chemosphere.2021.129584

95. Mehta, S., Shin, H., Burnett, R., North, T., Cohen, A.J., 2013. Ambient particulate air pollution and acute 
disease. Air Qual Atmos Health 6, 69-83. https://doi.org/10.1007/s11869-011-0146-3

96. Mele, M., Magazzino, C., Schneider, N., Strezov, V., 2021. NO2 levels as a contributing factor to COVID19 deaths: The first empirical estimate of threshold values. Environmental Research 194, 110663. https://doi.org/10.1016/j.envres.2020.110663

97. Menebo, M.M., 2020. Temperature and precipitation associate with Covid-19 new daily cases: A correlation study between weather and Covid-19 pandemic in Oslo, Norway. Science of The Total Environment 737, 139659. https://doi.org/10.1016/j.scitotenv.2020.139659

98. Mollalo, A., Vahedi, B., Rivera, K.M., 2020. GIS-based spatial modeling of COVID-19 incidence rate in the continental United States. Science of The Total Environment 728, 138884. https://doi.org/10.1016/j.scitotenv.2020.138884

99. Moniruzzam, M., Roy, A., Bhatt, C.M., Gupta, A., An, N.T.T., Hassan, M.R., 2018. Impact Analysis of Urbanization on Land Use Land Cover Change for Khulna City, Bangladesh using Temporal Landsat Imagery. Int. Arch. Photogramm. Remote Sens. Spatial Inf. Sci. XLII-5, 757-760. https://doi.org/10.5194/isprs-archives-XLII-5-757-2018

100. Nanda, C., Kant, Y., Gupta, A., Mitra, D., 2018. Spatio-Temporal Distribution of Pollutant Trace Gases During Diwali Over India. ISPRS Ann. Photogramm. Remote Sens. Spatial Inf. Sci. IV-5, 339-350. https://doi.org/10.5194/isprs-annals-IV-5-339-2018

101. Naqvi, H.R., Datta, M., Mutreja, G., Siddiqui, M.A., Naqvi, D.F., Naqvi, A.R., 2021. Improved air quality and associated mortalities in India under COVID-19 lockdown. Environ Pollut 268, 115691. https://doi.org/10.1016/j.envpol.2020.115691

102. Nigam, R., Pandya, K., Luis, A.J., Sengupta, R., Kotha, M., 2021. Positive effects of COVID-19 lockdown on air quality of industrial cities (Ankleshwar and Vapi) of Western India. Sci Rep 11, 4285. https://doi.org/10.1038/s41598-021-83393-9

103. Nottmeyer, L.N., Sera, F., 2021. Influence of temperature, and of relative and absolute humidity on COVID-19 incidence in England - A multi-city time-series study. Environ Res 196, 110977. https://doi.org/10.1016/j.envres.2021.110977

104. Oliveiros, B., Caramelo, L., Ferreira, N.C., Caramelo, F., 2020. Role of temperature and humidity in the modulation of the doubling time of COVID-19 cases. medRxiv 2020.03.05.20031872. https://doi.org/10.1101/2020.03.05.20031872

105. Orru, H., Ebi, K.L., Forsberg, B., 2017. The Interplay of Climate Change and Air Pollution on Health. Curr Envir Health Rpt 4, 504-513. https://doi.org/10.1007/s40572-017-0168-6

106. Pani, S.K., Lin, N.-H., RavindraBabu, S., 2020. Association of COVID-19 pandemic with meteorological parameters over Singapore. Science of The Total Environment 740, 140112. https://doi.org/10.1016/j.scitotenv.2020.140112

107. Pansini, R., Fornacca, D., 2020. COVID-19 higher induced mortality in Chinese regions with lower air quality. medRxiv 2020.04.04.20053595. https://doi.org/10.1101/2020.04.04.20053595

108. Perlman, S., 2020. Another Decade, Another Coronavirus. New England Journal of Medicine 382, 
109. Peters, A., Dockery, D.W., Muller, J.E., Mittleman, M.A., 2001. Increased Particulate Air Pollution and the Triggering of Myocardial Infarction. Circulation 103, 2810-2815.

https://doi.org/10.1161/01.CIR.103.23.2810

110. Pica, N., Bouvier, N.M., 2012. Environmental factors affecting the transmission of respiratory viruses. Curr Opin Virol 2, 90-95. https://doi.org/10.1016/j.coviro.2011.12.003

111. Prabhu, V., Soni, A., Madhwal, S., Gupta, A., Sundriyal, S., Shridhar, V., Sreekanth, V., Mahapatra, P.S., 2020. Black carbon and biomass burning associated high pollution episodes observed at Doon valley in the foothills of the Himalayas. Atmospheric Research 243, 105001. https://doi.org/10.1016/j.atmosres.2020.105001

112. Price, R.H.M., Graham, C., Ramalingam, S., 2019. Association between viral seasonality and meteorological factors. Scientific Reports 9, 929. https://doi.org/10.1038/s41598-018-37481-y

113. Qi, H., Xiao, S., Shi, R., Ward, M.P., Chen, Y., Tu, W., Su, Q., Wang, W., Wang, X., Zhang, Z., 2020. COVID19 transmission in Mainland China is associated with temperature and humidity: A time-series analysis. Science of The Total Environment 728, 138778.

https://doi.org/10.1016/j.scitotenv.2020.138778

114. Rendana, M., 2020. Impact of the wind conditions on COVID-19 pandemic: A new insight for direction of the spread of the virus. Urban Clim 34, 100680. https://doi.org/10.1016/j.uclim.2020.100680

115. Rosario, D.K.A., Mutz, Y.S., Bernardes, P.C., Conte-Junior, C.A., 2020. Relationship between COVID-19 and weather: Case study in a tropical country. International Journal of Hygiene and Environmental Health 229, 113587. https://doi.org/10.1016/j.ijheh.2020.113587

116. Rosenthal, F.S., Kuisma, M., Lanki, T., Hussein, T., Boyd, J., Halonen, J.I., Pekkanen, J., 2013. Association of ozone and particulate air pollution with out-of-hospital cardiac arrest in Helsinki, Finland: Evidence for two different etiologies. Journal of Exposure Science \& Environmental Epidemiology 23, 281-288. https://doi.org/10.1038/jes.2012.121

117. Rousta, I., Olafsson, H., Moniruzzaman, M., Zhang, H., Liou, Y.-A., Mushore, T.D., Gupta, A., 2020. Impacts of Drought on Vegetation Assessed by Vegetation Indices and Meteorological Factors in Afghanistan. Remote Sensing 12, 2433. https://doi.org/10.3390/rs12152433

118. Rume, T., Islam, S.M.D.-U., 2020. Environmental effects of COVID-19 pandemic and potential strategies of sustainability. Heliyon 6. https://doi.org/10.1016/j.heliyon.2020.e04965

119. Runkle, J.D., Sugg, M.M., Leeper, R.D., Rao, Y., Matthews, J.L., Rennie, J.J., 2020. Short-term effects of specific humidity and temperature on COVID-19 morbidity in select US cities. Sci Total Environ 740, 140093. https://doi.org/10.1016/j.scitotenv.2020.140093

120. Saadat, S., Rawtani, D., Hussain, C.M., 2020. Environmental perspective of COVID-19. Science of The Total Environment 728, 138870. https://doi.org/10.1016/j.scitotenv.2020.138870

121. Şahin, M., 2020. Impact of weather on COVID-19 pandemic in Turkey. Science of The Total Environment 728, 138810. https://doi.org/10.1016/j.scitotenv.2020.138810

122. Saikawa, E., Panday, A., Kang, S., Gautam, R., Zusman, E., Cong, Z., Somanathan, E., Adhikary, B., Loading [MathJax]/jax/output/CommonHTML/fonts/TeX/fontdata.js lester, P., Mishra, A., Mukherji, A., Shrestha, A.B. 
(Eds.), The Hindu Kush Himalaya Assessment: Mountains, Climate Change, Sustainability and People. Springer International Publishing, Cham, pp. 339-387. https://doi.org/10.1007/978-3-31992288-1_10

123. Sangkham, S., Thongtip, S., Vongruang, P., 2021. Influence of air pollution and meteorological factors on the spread of COVID-19 in the Bangkok Metropolitan Region and air quality during the outbreak. Environ Res 197, 111104. https://doi.org/10.1016/j.envres.2021.111104

124. Sathian, B., Asim, M., Banerjee, I., Pizarro, A.B., Roy, B., van Teijlingen, E.R., do Nascimento, I.J.B., Alhamad, H.K., 2020. Impact of COVID-19 on clinical trials and clinical research: A systematic review. Nepal J Epidemiol 10, 878-887. https://doi.org/10.3126/nje.v10i3.31622

125. Schmidt, C.W., 2011. Black Carbon: The Dark Horse of Climate Change Drivers. Environ Health Perspect 119, A172-A175.

126. Selcuk, M., Gormus, S., Guven, M., 2021. Impact of Weather Parameters and Population Density on the COVID-19 Transmission: Evidence from 81 Provinces of Turkey. Earth Syst Environ 5, 87-100. https://doi.org/10.1007/s41748-020-00197-z

127. Shakil, M.H., Munim, Z.H., Tasnia, M., Sarowar, S., 2020. COVID-19 and the environment: A critical review and research agenda. Science of The Total Environment 745, 141022. https://doi.org/10.1016/j.scitotenv.2020.141022

128. Sharma, G.D., Bansal, S., Yadav, A., Jain, M., Garg, I., 2021. Meteorological factors, COVID-19 cases, and deaths in top 10 most affected countries: an econometric investigation. Environ Sci Pollut Res. https://doi.org/10.1007/s11356-021-12668-5

129. Shi, P., Dong, Y., Yan, H., Zhao, C., Li, X., Liu, W., He, M., Tang, S., Xi, S., 2020. Impact of temperature on the dynamics of the COVID-19 outbreak in China. Science of The Total Environment 728, 138890. https://doi.org/10.1016/j.scitotenv.2020.138890

130. Sil, A., Kumar, V.N., 2020. Does weather affect the growth rate of COVID-19, a study to comprehend transmission dynamics on human health. Journal of Safety Science and Resilience 1, 3-11. https://doi.org/10.1016/j.jnlssr.2020.06.004

131. Singh, R.P., Chauhan, A., 2020. Impact of lockdown on air quality in India during COVID-19 pandemic. Air Qual Atmos Health 1-8. https://doi.org/10.1007/s11869-020-00863-1

132. Suhaimi, N.F., Jalaludin, J., 2015. Biomarker as a research tool in linking exposure to air particles and respiratory health. Biomed Res Int 2015, 962853. https://doi.org/10.1155/2015/962853

133. Suhaimi, N.F., Jalaludin, J., Latif, M.T., 2020. Demystifying a Possible Relationship between COVID19, Air Quality and Meteorological Factors: Evidence from Kuala Lumpur, Malaysia. Aerosol Air Qual. Res. 20, 1520-1529. https://doi.org/10.4209/aaqr.2020.05.0218

134. Tan, J., Mu, L., Huang, J., Yu, S., Chen, B., Yin, J., 2005. An initial investigation of the association between the SARS outbreak and weather: with the view of the environmental temperature and its variation. J Epidemiol Community Health 59, 186-192. https://doi.org/10.1136/jech.2004.020180

135. Tang, S., Mao, Y., Jones, R.M., Tan, Q., Ji, J.S., Li, N., Shen, J., Lv, Y., Pan, L., Ding, P., Wang, X., Wang, 
control. Environment International 144, 106039. https://doi.org/10.1016/j.envint.2020.106039

136. Thurston, G.D., Kipen, H., Annesi-Maesano, I., Balmes, J., Brook, R.D., Cromar, K., De Matteis, S., Forastiere, F., Forsberg, B., Frampton, M.W., Grigg, J., Heederik, D., Kelly, F.J., Kuenzli, N., Laumbach, R., Peters, A., Rajagopalan, S.T., Rich, D., Ritz, B., Samet, J.M., Sandstrom, T., Sigsgaard, T., Sunyer, J., Brunekreef, B., 2017. A joint ERS/ATS policy statement: what constitutes an adverse health effect of air pollution? An analytical framework. Eur Respir J 49. https://doi.org/10.1183/13993003.004192016

137. Tosepu, R., Gunawan, J., Effendy, D.S., Ahmad, L.O.A.I., Lestari, H., Bahar, H., Asfian, P., 2020. Correlation between weather and Covid-19 pandemic in Jakarta, Indonesia. Science of The Total Environment 725, 138436. https://doi.org/10.1016/j.scitotenv.2020.138436

138. Tuttle, K.R., 2020. Impact of the COVID-19 pandemic on clinical research. Nature Reviews Nephrology 16, 562-564. https://doi.org/10.1038/s41581-020-00336-9

139. Venter, Z.S., Aunan, K., Chowdhury, S., Lelieveld, J., 2020. COVID-19 lockdowns cause global air pollution declines. PNAS 117, 18984-18990. https://doi.org/10.1073/pnas.2006853117

140. Wang, C., Horby, P.W., Hayden, F.G., Gao, G.F., 2020. A novel coronavirus outbreak of global health concern. The Lancet 395, 470-473. https://doi.org/10.1016/S0140-6736(20)30185-9

141. Wang, J., Yu, A., Yang, L., Fang, C., 2019. Research on Organic Carbon and Elemental Carbon Distribution Characteristics and Their Influence on Fine Particulate Matter (PM2.5) in Changchun City. Environments 6, 21. https://doi.org/10.3390/environments6020021

142. Wang, M., Jiang, A., Gong, L., Luo, L., Guo, W., Li, Chuyi, Zheng, J., Li, Chaoyong, Yang, B., Zeng, J., Chen, Y., Zheng, K., Li, H., 2020. Temperature significant change COVID-19 Transmission in 429 cities. medRxiv 2020.02.22.20025791. https://doi.org/10.1101/2020.02.22.20025791

143. Wang, Y., Wang, Yuyi, Chen, Y., Qin, Q., 2020. Unique epidemiological and clinical features of the emerging 2019 novel coronavirus pneumonia (COVID-19) implicate special control measures. Journal of Medical Virology 92, 568-576. https://doi.org/10.1002/jmv.25748

144. White, M.P., Alcock, I., Grellier, J., Wheeler, B.W., Hartig, T., Warber, S.L., Bone, A., Depledge, M.H., Fleming, L.E., 2019. Spending at least 120 minutes a week in nature is associated with good health and wellbeing. Scientific Reports 9, 7730. https://doi.org/10.1038/s41598-019-44097-3

145. Winiger, P., Andersson, A., Eckhardt, S., Stohl, A., Gustafsson, Ö., 2016. The sources of atmospheric black carbon at a European gateway to the Arctic. Nature Communications 7, 12776. https://doi.org/10.1038/ncomms12776

146. Wu, X., Nethery, R.C., Sabath, M.B., Braun, D., Dominici, F., 2020. Air pollution and COVID-19 mortality in the United States: Strengths and limitations of an ecological regression analysis. Science Advances 6, eabd4049. https://doi.org/10.1126/sciadv.abd4049

147. Wu, Z., McGoogan, J.M., 2020. Characteristics of and Important Lessons From the Coronavirus Disease 2019 (COVID-19) Outbreak in China: Summary of a Report of 72314 Cases From the Chinese Center for Disease Control and Prevention. JAMA 323, 1239. 
148. Xie, J., Zhu, Y., 2020. Association between ambient temperature and COVID-19 infection in 122 cities from China. Science of The Total Environment 724, 138201.

https://doi.org/10.1016/j.scitotenv.2020.138201

149. Xing, Y.-F., Xu, Y.-H., Shi, M.-H., Lian, Y.-X., 2016. The impact of PM2.5 on the human respiratory system. J Thorac Dis 8, E69-E74. https://doi.org/10.3978/j.issn.2072-1439.2016.01.19

150. Yuan, J., Wu, Y., Jing, W., Liu, J., Du, M., Wang, Y., Liu, M., 2021. Non-linear correlation between daily new cases of COVID-19 and meteorological factors in 127 countries. Environ Res 193, 110521. https://doi.org/10.1016/j.envres.2020.110521

151. Zhang, D., Li, Y., Chen, Q., Jiang, Y., Chu, C., Ding, Y., Yu, Y., Fan, Y., Shi, J., Luo, Y., Zhou, W., 2019. The relationship between air quality and respiratory pathogens among children in Suzhou City. Italian Journal of Pediatrics 45, 123. https://doi.org/10.1186/s13052-019-0702-2

152. Zhang, H., Wang, Z., 2011. Advances in the Study of Black Carbon Effects on Climate. Advances in Climate Change Research 2, 23-30. https://doi.org/10.3724/SP.J.1248.2011.00023

153. Zhang, Z., Xu, X., Qiao, L., Gong, D., Kim, S.-J., Wang, Y., Mao, R., 2018. Numerical simulations of the effects of regional topography on haze pollution in Beijing. Sci Rep 8, 5504. https://doi.org/10.1038/s41598-018-23880-8

154. Zhu, N., Zhang, D., Wang, W., Li, X., Yang, B., Song, J., Zhao, X., Huang, B., Shi, W., Lu, R., Niu, P., Zhan, F., Ma, X., Wang, D., Xu, W., Wu, G., Gao, G.F., Tan, W., 2020. A Novel Coronavirus from Patients with Pneumonia in China, 2019. N Engl J Med 382, 727-733. https://doi.org/10.1056/NEJMoa2001017

155. Zhu, Y., Xie, J., Huang, F., Cao, L., 2020. Association between short-term exposure to air pollution and COVID-19 infection: Evidence from China. Sci Total Environ 727, 138704. https://doi.org/10.1016/j.scitotenv.2020.138704

156. Zoran, M.A., Savastru, R.S., Savastru, D.M., Tautan, M.N., 2020. Assessing the relationship between ground levels of ozone (O3) and nitrogen dioxide (NO2) with coronavirus (COVID-19) in Milan, Italy. Science of The Total Environment 740, 140005. https://doi.org/10.1016/j.scitotenv.2020.140005

157. Zu, Z.Y., Jiang, M.D., Xu, P.P., Chen, W., Ni, Q.Q., Lu, G.M., Zhang, L.J., 2020. Coronavirus Disease 2019 (COVID-19): A Perspective from China. Radiology 200490.

https://doi.org/10.1148/radiol.2020200490

\section{Figures}




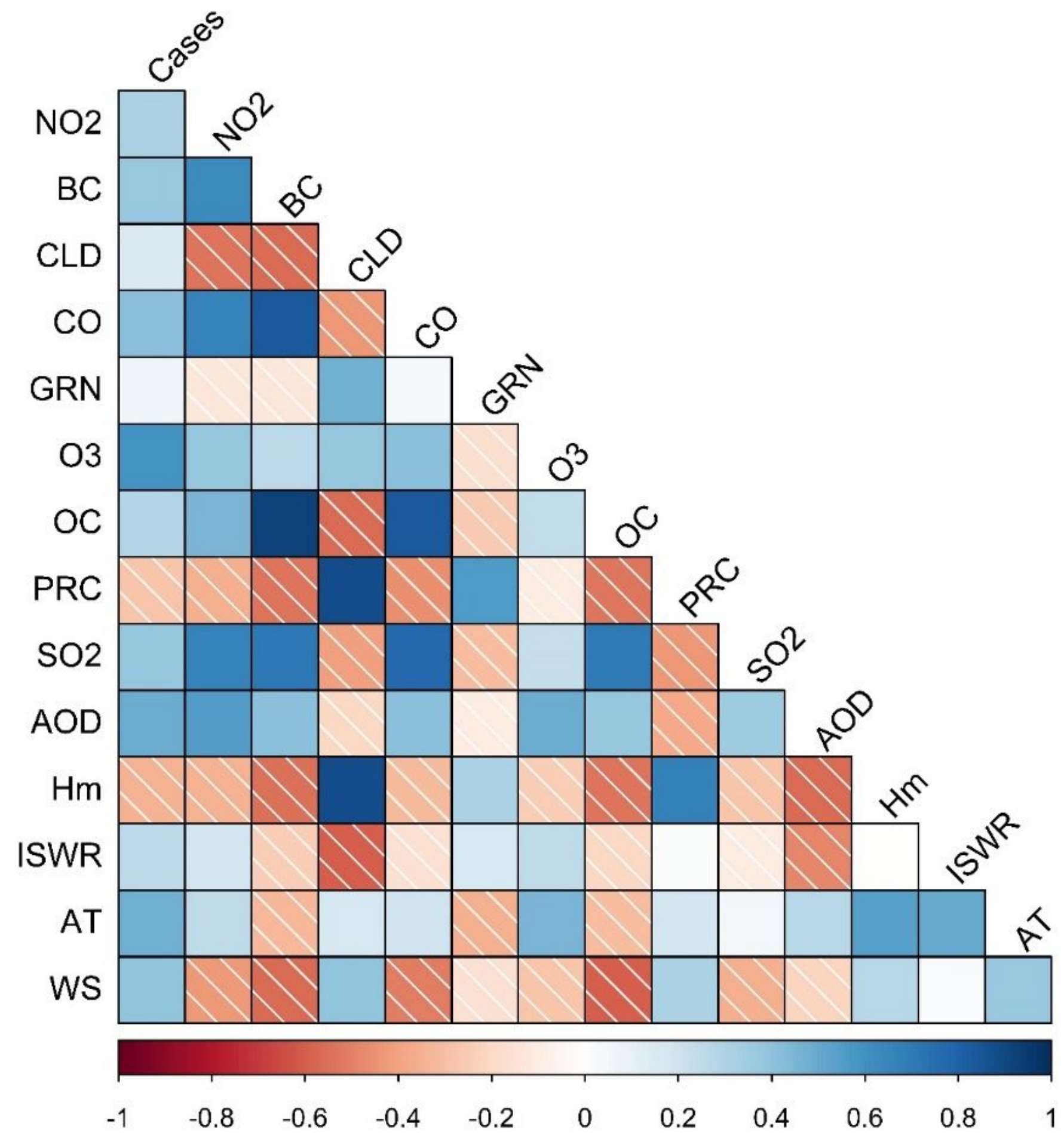

Figure 1

Correlogram for the present analysis 